Developing Countries and New Democracies Matter: An Overview of Research on State Feminism Worldwide Celia Valiente, Universidad Carlos III de Madrid

DOI: 10.1017/S1743923X07000372

\title{
Introduction
}

Since the 1970s, institutions with the explicit purpose of advancing women's rights and status have been established in an overwhelming majority of countries. In political science research, these institutions usually are called "women's policy machineries," "state feminist institutions," or "gender equality agencies." The people who work in them are often referred to as "state feminists." This article offers a general overview of academic studies on state feminism, the majority of which were published in the last decade. Generally speaking and with few exceptions, social scientists researching state feminism in postindustrial countries tend to consider only academic work on other postindustrial countries and ignore scholarly analyses of developing 
countries and new democracies. Countries outside the postindustrial world have women's institutions, and there is no reason to disregard them.

By taking into consideration what is already known about state feminism in the rest of the globe, scholars who specialize in postindustrial states could begin to solve three main flaws of the literature on state feminism in postindustrial countries (hereafter the "postindustrial literature" or "postindustrial research"). These three flaws are unsatisfactory definitions of state feminism, incomplete analyses of the factors that influence the policy effectiveness of women's agencies, and incorrect assumptions for the study of the relationship between gender equality offices and women's movements.

Postindustrial research frequently defines state feminism in terms that are excessively difficult to achieve in the real world; it requires a high threshold of policy change in order for an agency to be considered feminist. Prevailing definitions require that agencies promote policies that benefit all women, undermine gender hierarchies, include the demands of the women's movement in the policy process, and help women's movement actors gain access to policy arenas. According to some of the definitions that prevail in postindustrial research, few agencies could ever reach state feminist status. Ultimately, the very object of study (state feminism) would disappear for research. On the other hand, some current definitions require women's units to do too little in order to qualify as "state feminist," sometimes requiring the adoption of gender equality policies regardless of whether such policies are finally implemented or not. Thus, women's units that advance only symbolic or cosmetic measures are sometimes incorrectly identified as "state feminist."

With respect to the analysis of the policy influence of women's machineries, part of the scholarship on the developing world and new democracies questions the importance conferred by the postindustrial literature to some factors, such as feminist leadership and staff, or crosssectoral mandates. Moreover, at least four variables highly relevant to developing countries receive little attention in postindustrial analyses: state capacity, political instability, policy legacies, and material and human resources.

As regards the study of the relationship between women's institutions and women's movements, the postindustrial literature should imitate the literature on the rest of the globe while acknowledging that the feminist movement is not synonymous with the women's movement. Furthermore, postindustrial literature relies on a dichotomy between state and society (women's policy agencies and women's movements), 
but this dichotomy is a false one. This dichotomy should probably be replaced by the notion of a continuum of women's activism in various settings suggested by scholarship on developing countries and new democracies.

\section{Definitions of State Feminism}

The association of the term "state feminism" with women's policy agencies and the diffusion of the term occurred mainly because of the high academic impact of the first cross-national study on the matter under review here: Dorothy McBride Stetson and Amy Mazur's Comparative State Feminism. This book examines "government structures that are formally charged with furthering women's status and rights" in 13 postindustrial countries and a then-emerging democracy (Poland) (Stetson and Mazur 1995, 1-2). According to this seminal book, women's policy offices achieve state feminism when fulfilling two conditions: They "contribute to policies that reduce gender-based inequities and provide an opportunity for women's movement activists to influence feminist policy formation" (p. 2). In addition, "An ideology, policy, organization, or activity is feminist to the extent that it has the purpose of improving the status of women as a group and undermining patterns of gender hierarchy" (p. 16). Focusing mainly on the specific policy area of equal employment, Stetson and Mazur (pp. 272-73) conclude that in all cases except the state-affiliated women's organization of the Polish communist state, the Liga Kobiet, women's agencies produced state feminism, though to different degrees.

This definition of state feminism presupposes that "women as a group" benefit from feminist policies advanced by women's state units. But women are a very heterogeneous sector of the population. Scholarship on state feminism in the developing world and new democracies documents the vast class and ethnic differences that distinguish women in many countries (Lievesley 1996, 46; Lycklama à Nijeholt, Vargas, and Wieringa. 1998, 78). Therefore, it is highly probable that policies advanced by gender equality institutions benefit some women but not others (Richards 2004, 50-52, 102).

After the publication of Comparative State Feminism, Stetson and Mazur founded an international network of scholars to investigate women's agencies in postindustrial countries: the Research Network on Gender Politics and the State (RNGS). The RNGS team attempts to 
study the impact of women's offices on policy debates about topics of political importance in postindustrial countries since the 1970s, including job training, abortion, prostitution, political representation, and "hot issues," which are matters of high salience that differ from country to country. The RNGS team specified two conditions for state feminism: that women's policy machineries manage to insert into policy deliberations and policy content the demands advanced by the women's movement, and that they help women's movement actors gain access to the policy discussion. This is the definition used by many of the leading publications of RNGS scholars (e.g., Lovenduski 2005, 14; Mazur 2001, 5-7; Outshoorn 2004, 2; Stetson 2001, 8, 11). The RNGS team concluded that in general and with exceptions, state feminism occurred in postindustrial countries in the policy areas of abortion, prostitution, and political representation (though to different degrees) (Lovenduski 2005, 292; Outshoorn 2004, 280-92; Stetson 2001, 282-83). In contrast, state feminism tended to be rarer in the policy area of job training (Mazur 2001, 295, 301).

The RNGS requirement that women's units bring to the policy process the demands of the women's movement in order to be typified as "state feminist" is excessive, because this requirement entails the very existence of these clear demands. But as research on developing countries and new democracies shows, in some countries where women's units exist, the women's movement may be at a very incipient stage of development and, therefore, unable to formulate many demands. Other times, the women's movement may not have advanced demands related to some policy areas (Friedman 2000a, 2000b; Rai 2003). Finally, the RNGS definition of state feminism presupposes that the activities of women's units and the demands advanced by the women's movement are variables relatively independent from each other. However, as I will explain, this may not be the case because in many countries, women's units subsidize women's groups and may therefore intensively influence their demands.

Both Comparative State Feminism and the RNGS project require women's policy agencies to help women's movement actors gain access to the policymaking process in order to be classified as "state feminist." This precondition is also exaggerated because it impedes researchers to typify as state feminist those women's units that foster decisive gender equality reforms without helping women's movement actors reach policy arenas. All over the world, progressive reforms on the status of women have been undertaken by coalitions of political and social actors that may 
not include members of the women's movement (Htun 2003). If such coalitions comprise women's agencies, these should be termed "state feminist."

There is a sense in which some postindustrial definitions of state feminism, such as that of RNGS, ask too little of women's offices to categorize them as state feminist: that they simply contribute to the formation of feminist policies (Lovenduski 2005, 14-15; Mazur 2001, 5-7; Outshoorn 2004, 2; Stetson 2001, 8, 11). The focus on policy formation is clearly insufficient because policies may not be implemented (Nelson and Chowdhury 1994, 314; Rai 2003). Policies that are not implemented are symbolic policies. Such policies do not tackle the problems they are supposed to solve because they fail to generate a network of state and societal actors interested in the successful implementation of these policies (Mazur 1995, 2-3).

\section{Policy Effectiveness of Women's Agencies}

The policy effectiveness of women's agencies is one of the topics that has received the most attention by scholars studying state feminism all over the world. The literatures on state feminism in all types of countries agree on the importance of some factors in explaining the policy impact of women's machineries. One example is the ideological color of the administration. In general and with important exceptions, left or progressive political forces in power tend to facilitate state feminism (Baldez 2001; Ferree 1991-92, 54-56; Lovenduski 2005, 284; Stetson 2001, 286, 295). Conservative political and social actors tend to hinder the policy effectiveness of women's units (Bayes and Tohidi 2001, 215; Berik 1990; Rai 2003, 235).

The scholarship on state feminism has also concluded that feminist leadership and staff usually facilitate the feminist policy influence of women's units (Baldez 2001, 17-18; Caldeira 1998, 77-78; Franceschet 2003, 12-13; Lovenduski 2005, 273; Outshoorn 2004, 284, 291; Sawer 1990). If the director and part of the staff of a gender equality unit actually participate in the feminist movement, they will know the priorities of the movement, and (usually) will have the personal commitment necessary to further feminist goals (Rai 2003, 131-32).

In contrast, other studies of developing countries and new democracies argue that feminist leadership is not an essential ingredient in the recipe for effective women's policy machineries. At times, agencies have been headed 
by women with no previous record in feminist mobilizations but with an indepth knowledge of the political world and/or the bureaucracy, and/or personal ties with members of the political class and the bureaucratic elite. The knowledge and personal ties have been extremely useful for advancing feminist reform (Friedman 2000a, 59, 63; 2000b, 180, 198; Matear 1995, 112-13; Waylen 1996, 109-11). Therefore, perhaps one of the components of the policy success of feminist institutions is what Friedman (2000a, 73) calls "dynamic leadership," rather than feminist leadership.

Part of the postindustrial literature concludes that with exceptions, cross-sectoral mandates usually enhance the policy impact of gender equality units, since these mandates intervene in different policy areas such as education, work, and sexuality. Gender hierarchies are multidimensional. Thus, cross-sectoral institutions are supposed to be better equipped to tackle gender inequality than institutions with a mandate in only one policy area (Outshoorn 2004, 291; Stetson and Mazur 1995, 288).

Scholarship on the developing world and new democracies has questioned whether cross-sectoral mandates are normally a characteristic of the most effective women's policy agencies (Friedman 2000a, 74). The implementation of a cross-sectoral mandate is a hard task because it implies the coordination of state units that are accustomed to functioning independently (Lycklama à Nijeholt, Vargas, and Wieringa 1998, 132-33). Bureaucratic units tend to protect their autonomy zealously (Rai 2003, 79; Waylen 1996, 110-11). Women's machineries do not have the power to punish state units that fail to implement gender equality policies. Cross-sectoral mandates are often very broad mandates. They are impossible to fulfill with modest material and human resources (Lewis 1990; Rai 2003, 237).

Postindustrial scholarship has not considered seriously that some factors influence the policy impact of women's units, including state capacity, political instability, policy legacies, and material and human resources. Research on developing countries and new democracies suggests that these four factors are significant.

Discussions regarding the general capacity of the state to implement public policy are usually absent in the literature on women's machineries in the postindustrial world. This is surprising, given that this scholarship claims to be about state feminism. By contrast, research on developing countries and new democracies rightly indicates that such state capacity matters when studying the record of the policy 
effectiveness of institutions in general, or feminist institutions in particular (Lycklama à Nijeholt, Vargas, and Wieringa 1998, 79; Sperling 1999, 143).

Political instability has been identified by studies on state feminism in the developing part of the globe and new democracies as a factor that seriously reduces the policy influence of women's machineries. Constant changes of government may entail frequent changes of directors of women's institutions and, hence, a lack of long-term gender equality policy. Government instability may imply job insecurity for the director and staff of agencies and a subsequent lack of job motivation. The party or coalition in office may be very busy trying to remain in power and therefore unable to pay attention to other aims perceived as less pressing, such as the advancement of gender equality (Rai 2003, 102, 119, 234).

As regards policy legacies, studies on new democracies argue that the historical past can hinder the creation and policy effectiveness of women's policy machineries and the appearance of autonomous women's movements. For instance, in Central and Eastern Europe, the official propaganda of the socialist/communist regimes prior to the current democracies emphasized state efforts to liberate women from their subordinate position. Official discourses proclaimed the superiority of these left-wing nondemocratic regimes regarding the status of women in comparison with capitalist countries. When socialist/communist regimes collapsed in the late 1980s and early 1990s, important sectors of the female population and the governing elite were highly suspicious of institutions and state policies directed toward women and the conceptualization of women as a special social category (Baldez 2003, 257, 266; Basu 1995, 366-67; Sperling 1999, 48).

Finally, as for material and human resources, with a partial exception (Outshoorn 2004, 284, 291), neither Comparative State Feminism (Stetson and Mazur 1995) nor the RNGS project have found that the budget and staff of women's policy units significantly foster or hamper the policy effectiveness of women's units (Lovenduski 2005, 273-74; Mazur 2001, 295, 306; Stetson 2001, 284). This is amazing, because as mentioned, these agencies usually have very broad mandates. In contrast, research on the remaining part of the world usually declares that inadequate material and human resources are one of the endemic problems of many feminist agencies. Reduced staff and budgets seriously hinder the capacity of women's units to exert influence in the policy process (Alvarez 1990; Baldez 2001, 18; Friedman 2000a, 74; Htun 2001; Lewis 1990; Rai 2003, 27-28, 76-77, 99-100, 210). 


\section{Relations with the Women's Movement}

Studies on state feminism in all parts of the world have analyzed intensively the relationships between women's units and women's movements. At times, the demands of the women's movement (or of some sectors of the women's movement) were (with other causes) at the very origin of women's policy machineries in all sorts of polities (Alvarez 1999, 191; Caldeira 1998, 76; Eisenstein 1996, xii; Rai 2003, 131-33, 181; Stetson and Mazur 1995, 61; Watson 1990). Research on all types of countries emphasizes the importance of the pressure of the women's movement for the advancement of some of the most energetic campaigns undertaken by women's units (Alvarez 1990, 61, 72; Friedman 2000a, 74; Lovenduski 2005, 292; Stetson and Mazur 1995, 290).

Generally speaking and with few exceptions, postindustrial analyses on state feminism wrongly equate the women's movement with the feminist movement. Conversely, while studying the relationship between women's institutions and the women's movement, specialists on developing countries and new democracies carefully analyze the links between women's policy machineries and the different branches of the movement. In some cases, gender equality agencies tend to interact with feminist groups but more rarely (or hardly even) with other types of women's organizations (Bayes and Tohidi 2001, 164; Okeke-Ihejirika and Franceschet 2002, 447; Richards 2003, 2004).

Scholarship on developing countries and new democracies has highlighted the blurred boundary that often separates women's policy machineries from women's movements. This fuzzy frontier between states and movements is the result of several processes. In many developing countries and new democracies, because women's policy agencies are often understaffed and underfunded (as mentioned), they regularly subcontract many tasks to women's groups that in postindustrial countries are usually performed by the agencies themselves. These groups often adopt the formal structure of a nongovernmental organization. In numerous countries, state feminist institutions have been set up and dismantled in a short time span. Some of these institutions are in part staffed by women formerly active in the women's movement. When women's policy agencies are demoted or closed down, a section of their staff is employed in or collaborates with NGOs that work on women's projects (Caldeira 1998, 79; Lycklama à Nijeholt, Vargas, and Wieringa 1998, 83). 
The process by which individuals and organizations of the women's movement work regularly as subcontractors of government agencies (not necessarily women's policy agencies) has been named by Sonia Alvarez (1999) the "NGOization" of the women's movement. The consequences of the NGOization for the women's movement are numerous. On the positive side, by working in these NGOs, many female activists have jobs that are meaningful to them, instead of living in the unenviable situation of combining social movement activism with a job elsewhere that is necessary for economic survival but not rewarding at all. By working alternatively in the movement and the state, activists can be in a position to insert movement priorities into the policymaking process.

On the negative side, women activists find it more and more risky to protest against the very authorities that subcontract or subsidize them or their organizations or for whom they may work in the future. At times, the aforementioned divisions among different branches of the women's movement augment conflict within the movement, since the feminist strand obtains sub-contracts and subsidies more often than do the other strands. This happens, among other reasons, because many feminist activists are middle-class professionals with the adequate skills and contacts to deal with bureaucratic requirements (Schild 1995, 141-42; Waylen 1996, 114). Activists are often not free to choose their priorities but have to undertake only the types of projects that state bureaucrats are willing to finance (Alvarez 1999; Rai 2003, 103; Schild 1995, 126-27, 136-38).

\section{Conclusion}

That those who study postindustrial polities take into consideration the works on developing societies and new democracies is one of the next major steps in the future research on state feminism in political science. A revised version of the definitions of state feminism, the factors that influence the policy effectiveness of women's units, and the relationships between women's agencies and women's movements will help develop the study field on state feminism.

Taking seriously the contributions of scholarship on developing countries and new democracies means employing more modest notions of state feminism. I propose the following definition: A women's unit achieves state feminism if it contributes to the formulation of policies that sometimes help women as a group and other times help some sectors of the female population (different from the very officials of the women's 
unit and their acquaintances). An additional condition is also necessary: that these policies be implemented to a significant extent. Women's policy machineries can achieve different degrees of state feminism. The most active women's institutions promote numerous policies that benefit women as a group and undermine gender hierarchies. They may also include in the policymaking process the demands advanced by the women's movement (if such demands exist), and/or help women's movement actors gain an entry into public decision-making arenas (if movement actors clearly different from state feminists exist).

With respect to the factors that enhance or hinder the policy impact of women's agencies, research on developing countries and new democracies shows that the discussion on whether the leadership of women's units should be overtly feminist or not needs development in new directions. Rather than defining feminist leadership of women's agencies only as the previous membership of the leaders of the feminist movement, as postindustrial research does, new questions should be asked. For instance, to what extent does involvement in women's state machinery influence previously nonfeminist leaders? Similarly, what is the impact when a woman has had experience in women's issues but has not come out as feminist? The inquiry of what helps or hampers the effectiveness of women's units should also comprise the analysis of factors usually disregarded by postindustrial research, including general state capacity, political instability, and policy legacies. Material and human resources of women's agencies should be assessed in relation to the single or crosssectional mandates of agencies.

As regards the study of the relationship between women's units and women's movements, more research is needed to understand what circumstances (if any) make possible the forging of fruitful relations between women's institutions and the different branches of the women's movements in any given country. The increasing indeterminacy of the border that separates women's agencies from women's movements has often been noted by researchers on state feminism in developing countries and new democracies. The implications of this overlap between states and movements for both state policymaking and the women's movements is a promising line of future research. This overlapping suggests that the dichotomy between feminist institutions and the women's movements may be a false dichotomy. As recent analyses of women's movements argue (Banaszak 2004; Beckwith 2001, 383), it may be time to substitute the conventional distinction between states and movements by the notion of a continuum of women's activism in different locations. 


\section{REFERENCES}

Alvarez, Sonia E. 1990. "Contradictions of a 'Women's Space' in a Male-Dominant State: The Political Role of the Commissions on the Status of Women in Post-authoritarian Brazil." In Women, International Development, and Politics: The Bureaucratic Mire, ed. Kathleen, Staudt. Philadelphia: Temple University Press, 37-78.

Alvarez, Sonia E. 1999. "Advocating Feminism: The Latin American Feminist NGO 'Boom." International Feminist Journal of Politics 1 (2): 181-209.

Baldez, Lisa. 2001. "Coalition Politics and the Limits of State Feminism in Chile." Women \& Politics 22 (4): 1-28.

Baldez, Lisa. 2003. "Women's Movements and Democratic Transitions in Brazil, Chile, East Germany and Poland." Comparative Politics 35 (3): 253-72.

Banaszak, Lee A. 2004. "Mobilizing in and out of the State: Feminist Bureaucrats and the Creation of Women's Movement Organizations." Paper presented at the Annual Meeting of the American Political Science Association, Chicago.

Basu, Amrita, ed. 1995. The Challenge of Local Feminisms: Women's Movements in Global Perspectives. Boulder, CO: Westview Press.

Bayes, Jane H., and Nayereh, Tohidi, eds. 2001. Globalization, Gender, and Religion: The Politics of Women's Rights in Catholic and Muslim Contexts. New York: Palgrave.

Beckwith, Karen. 2001. "Women's Movements at Century's End: Excavation and Advances in Political Science." Annual Review of Political Science 4: 371-90.

Berik, Günseli. 1990. "State Policy in the 1980s and the Future of Women's Rights in Turkey." New Perspectives on Turkey (4 Fall): 81-96.

Caldeira, Teresa P.R. 1998. "Justice and Individual Rights: Challenges for Women's Movements and Democratization in Brazil." In Women and Democracy: Latin America and Central and Eastern Europe, ed. Jane S. Jaquette and Sharon L. Wolchik. Baltimore: The John Hopkins University Press, 75-103.

Eisenstein, Hester. 1996. Inside Agitators: Australian Femocrats and the State. Philadelphia: Temple University Press.

Ferree, Myra Marx. 1991-92. "Institutionalizing Gender-Equality: Feminist Politics and Equality Offices." German Politics and Society 24 and 25 Winter: 53-64.

Franceschet, Susan. 2003. "State Feminism' and Women's Movements: The Impact of Chile's Servicio Nacional de la Mujer on Women's Activism.” Latin American Research Review 38 (1): 9-40.

Friedman, Elisabeth. 2000a. "State-Based Advocacy for Gender Equality in the Developing World: Assessing the Venezuelan National Women's Agency.” Women \& Politics 21 (2): $47-80$.

Friedman, Elisabeth. 2000b. Unfinished Transitions: Women and the Gendered Development of Democracy in Venezuela, 1936-1996. University Park: Pennsylvania State University Press.

Htun, Mala. 2001. "Advancing Women's Rights in the Americas: Achievements and Challenges.” Working paper, The Dante B. Fascell North-South Center, University of Miami.

Htun, Mala. 2003. Sex and the State: Abortion, Divorce and the Family under Latin American Dictatorships and Democracies. New York: Cambridge University Press.

Huntington, Samuel P. 1991. The Third Wave: Democratization in the Late Twentieth Century. Norman and London: University of Oklahoma Press.

Lewis, Barbara. 1990. "Farming Women, Public Policy, and the Women's Ministry: A Case Study from Cameroon." In Women, International Development and Politics: The Bureaucratic Mire, ed. Kathleen Staudt. Philadelphia: Temple University Press, 180-200. 
Lievesley, Geraldine. 1996. "Stages of Growth? Women Dealing with the State and Each Other in Peru." In Women and the State: International Perspectives, ed. Shirin M. Rai and Geraldine Lievesley. London: Francis \& Taylor, 45-60.

Lovenduski, Joni, ed. 2005. State Feminism and Political Representation. Cambridge: Cambridge University Press.

Lycklama à Nijeholt, Geertje, Virginia, Vargas, and Saskia, Wieringa, eds. 1998. Women's Movements and Public Policy in Europe, Latin America, and the Caribbean. New York: Garland.

Matear, Ann. 1995. "The Servicio Nacional de la Mujer (SERNAM): Women and the Process of Democratic Transition in Chile 1990-94." In Neo-liberalism with a Human Face? The Politics and Economics of the Chilean Model, ed. David E. Hojman. Liverpool: Institute of Latin American Studies, The University of Liverpool, 93-117.

Mazur, Amy G. 1995. Gender Bias and the State: Symbolic Reform at Work in Fifth Republic France. Pittsburgh: Pittsburgh University Press.

Mazur, Amy G., ed. 2001. State Feminism, Women's Movements, and Job Training: Making Democracies Work in the Global Economy. New York: Routledge.

Nelson, Barbara, and Najma, Chowdhury, eds. 1994. Women and Politics Worldwide. New Haven and London: Yale University Press.

Okeke-Ihejirika, Philomina E., and Susan, Franceschet. 2002. "Democratization and State Feminism: Gender Politics in Africa and Latin America." Development and Change $33(3): 439-66$

Outshoorn, Joyce. ed. 2004. The Politics of Prostitution: Women's Movements, Democratic States and the Globalization of Sex Commerce. Cambridge: Cambridge University Press.

Rai, Shirin M., ed. 2003. Mainstreaming Gender, Democratizing the State? Institutional Mechanisms for the Advancement of Women. Manchester and New York: Manchester University Press.

Richards, Patricia. 2003. "Expanding Women's Citizenship? Mapuche Women and Chile's National Women's Service." Latin American Perspectives 30 (2): 41-65.

Richards, Patricia. 2004. Pobladoras, Indígenas, and the State: Conflicts over Women's Rights in Chile. New Brunswick, NJ: Rutgers University Press.

Sawer, Marian. 1990. Sisters in Suits: Women and Public Policy in Australia. Sydney: Allen \& Unwin.

Schild, Verónica. 1995. "NGOs, Feminist Politics and Neo-liberal Latin American State Formations: Some Lessons from Chile." Canadian Journal of Developmental Studies Special Issue: 123-47.

Sperling, Valerie. 1999. Organizing Women in Contemporary Russia: Engendering Transition. Cambridge: Cambridge University Press.

Stetson, Dorothy McBride, ed. 2001. Abortion Politics, Women's Movements, and the Democratic State: A Comparative Study of State Feminism. New York: Oxford University Press.

Stetson, Dorothy McBride, and Amy, G. Mazur, eds. 1995. Comparative State Feminism. Thousand Oak, CAs: Sage.

Threlfall, Monica. 1998. "State Feminism or Party Feminism? Feminist Politics and the Spanish Institute of Women." European Journal of Women Studies 5 (1): 69-93.

Watson, Sophie, ed. 1990. Playing the State: Australian Feminist Interventions. London and New York: Verso.

Waylen, Georgina. 1996. "Democratization, Feminism and the State in Chile: The Establishment of SERNAM." In Women and the State: International Perspectives, ed. Shirin M. Rai and Geraldine Lievesley. London: Taylor \& Francis, 103-17 